Original Research Paper

\title{
Optimalisasi Pemanfaatan Lahan Kosong Berbasis Tanaman Sayur dan Apotek Hidup di Desa Sigar Penjalin Kecamatan Tanjung Kabupaten Lombok Utara
}

\author{
Bulkaini $^{1 *}$, Muhamad Aprizal Akbar ${ }^{2}$, Alya Maolani ${ }^{3}$, Slamet Pratama ${ }^{4}$, Lalu Naif Zaharani ${ }^{5}$, Eliza \\ Apriana $^{6}$, Sri Handayani ${ }^{7}$, Wahyu Akbar ${ }^{8}$, Fitri Handayani' \\ ${ }^{I}$ Fakultas Peternakan, Universitas Mataram, Mataram Indonesia \\ ${ }^{2}$ Program Studi Sosiologi Universitas Mataram, Mataram Indonesia \\ ${ }^{3}$ Program Studi Ilmu Komunikasi Universitas Mataram, Mataram Indonesia \\ ${ }^{4}$ Program Studi Pendidikan Sosiologi Universitas Mataram, Mataram Indonesia \\ ${ }^{5}$ Program Studi Pendidikan Bahasa Inggris FKIP, Universitas Mataram, Mataram Indonesia \\ ${ }^{6}$ Program Studi Pendidikan Matematika, FKIP, Universitas Mataram, Mataram Indonesia \\ ${ }^{7}$ Program Studi Bahasa dan Sastra Indonesia, FKIP, Universitas Mataram, Mataram Indonesia \\ ${ }^{8}$ Program Studi Ilmu Hukum, Fakultas Hukum, Universitas Mataram, Mataram Indonesia \\ ${ }^{9}$ Program Studi Budidaya Perairan, Universitas Mataram, Mataram Indonesia.
}

DOI: https://doi.org/10.29303/jpmpi.v4i2.706

Sitasi: Bulkaini., Akbar, M. A., Maolani, A., Pratama, S., Zaharani, L. N., Apriana, E., Handayani, S., Akbar, W., \& Handayani. (2021). Optimalisasi Pemanfaatan Lahan Kosong Berbasis Tanaman Sayur dan Apotek Hidup di Desa Sigar Penjalin Kecamatan Tanjung Kabupaten Lombok Utara. Jurnal Pengabdian Magister Pendidikan IPA, 4(2)

\section{Article history}

Received: 03 Februari 2021

Revised: 08 Maret 2021

Accepted: 13 April 2021

*Corresponding Author: Bulkaini, Fakultas Peternakan Universitas Mataram, Mataram Indonesia;

Email: b_kaini@yahoo.com

\begin{abstract}
Permasalahan yang dihadapi oleh masyarakat Desa Sigar Penjalin, Kecamatan Tanjung, Kabupaten Lombok Utara dalam mengembangkan konsep kawasan rumah pangan lestari melalui pemanfaatan lahan pekarangan adalah kurangnya pengetahuan dan pelatihan mengenai penyiapan media tanam dalam pot, penyediaan pupuk organik dan pot atau wadah tanaman dari bahan sekitar lingkungan. Tujuan program pengabdian masyarakat ini adalah (1) Meningkatkan pengetahuan dan keterampilan, kesadaran serta memotivasi masyarakat dalam pemanfaatan lahan kosong/pekarangan sebagai sumber pangan dan pendapatan keluarga; (2) Menerapkan beberapa teknik sederhana penanaman lahan pekarangan dan pemeliharaannya yang dapat diimplementasikan secara mudah oleh masyarakat. Metode kegiatan yang dilakukan adalah diskusi dan demonstrasi praktek langsung di lapangan. Hasil kegiatan pengabdian adalah: 1) Keterampilan warga masyarakat di Desa Sigar Penjalin meningkat dengan indikator bahwa masyarakat telah dapat menyiapkan media tanam untuk budidaya tanaman sayur dalam pot, serta pemanfaatan bahan-bahan sekitar untuk pembuatan pot/wadah dan pupuk organik cair; (2) Kegiatan pengabdian ini dapat menambah pengetahuan warga masyarakat tentang pentingnya pemanfaatan lahan pekarangan melalui penerapan konsep rumah pangan lestari untuk mendukung ketahanan pangan keluarga.
\end{abstract}

Keywords: Lahan kosong; Apotek hidup; Tanaman sayur.

\section{Pendahuluan}

Di Indonesia, isu ketahanan pangan merupakan fokus utama dalam kebijakan operasional pembangunan pertanian. Berdasarkan
Undang-Undang No. 7 tahun 1996, bahwa ketahanan pangan adalah kondisi terpenuhinya pangan bagi setiap rumah tangga yang tercermin dari tersedia dan tercukupinya pangan baik jumlah, mutu, aman, merata dan terjangkau (Handewi, 2011). 
Isu ketahanan pangan belakangan ini menjadi isu yang sangat strategi karena berkaitan dengan kecukupan gizi masyarakat. Kebijakan pemerintah dalam pembangunan ketahanan pangan di Indonesia mengisyaratkan tiga hal yang harus terpenuhi yaitu jumlahnya cukup, mutunya baik dan dapat dijangkau. Terpenuhinya pangan di setiap rumah tangga merupakan tujuan utama sekaligus sebagai sasaran dari ketahanan pangan di Indonesia (Saliem, 2011).

Masalah ketahanan pangan nasional merupakan masalah yang harus ditangani secara bersama. Tidak hanya mengandalkan pemerintah, namun harus didukung dengan keikutsertaan secara aktif masyarakat yang dimulai dari lini terkecil pembentuk masyarakat yaitu keluarga. Menurut Setyaningrum et al. (2016) bahwa rumah pangan merupakan salah satu konsep pemanfaatan lahan pekarangan baik di pedesaan maupun diperkotaan untuk mendukung ketahanan pangan nasional dengan memberdayakan potensi pangan lokal.

Dalam masyarakat pedesaan, kegiatan RPL (rekognisi pembelajaran lampau) sebenarnya telah lama dilakukan yaitu memanfaatkan lahan pekarangan dengan cara ditanami tanaman untuk kebutuhan sehari-hari, namun kegiatannya masih bersifat sambilan untuk mengisi waktu luang. Kegiatan ini apabila dikelola dengan baik akan memberikan nilai tambah berupa kecukupan gizi dan berpeluang meningkatkan penghasilan rumah tangga.

Pekarangan bukan hanya untuk menciptakan keindahan dan kesejukan saja, tetapi lebih dari pada itu adalah guna meningkatkan perekonomian keluarga masing-masing. Jenis-jenis tanaman yang bisa ditanam di pekarangan rumah masing-masing adalah jenis berbagai jenis tanaman sayur, buah-buahan, obat-obatan, tanaman hias, dan lain sebagainya yang kesemuanya itu dapat menunjang kebutuhan sehari-hari dan selebihnya bisa dijual. Menurut Tando (2018) bahwa pemanfaatan lahan pekarangan belum optimal dilakukan masyarakat dalam memenuhi kebutuhan pangan keluarga. Luas lahan pekarangan di Indonesia menurut catatan Kementerian Pertanian (2012) ialah 10.3 juta ha atau sebesar 14\% dari luas seluruh tanah pertanian rakyat (Kurniawan et al., 2018)

Secara umum, permasalahan dihadapi oleh masyarakat dalam mengembangkan konsep rumah pangan lestari melalui pemanfaatan lahan pekarangan adalah kurangnya pengetahuan dan pelatihan mengenai penyiapan media tanah, penyediaan pupuk organik cair dari limbah biogas dan pemanfaatan limbah disekitar lingkungan sebagai bahan pembuatan pot atau wadah tanaman. Tujuan dari program pengabdian masyarakat ini adalah: (1) Meningkatkan pengetahuan dan keterampilan, kesadaran serta memotivasi masyarakat dalam pemanfaatan lahan kosong / pekarangan sebagai sumber pangan dan pendapatan keluarga; dan (2) Menerapkan beberapa teknik sederhana penanaman lahan pekarangan dan pemeliharaannya yang dapat diimplementasikan secara mudah oleh masyarakat.

\section{Metode}

Sasaran kegiatan peningkatan ketahanan pangan melalui pemanfaatan lahan pekarangan dengan menerapkan konsep kawasan Rumah Pangan Lestari ini adalah di Pondok Pesantren AsSa'Idiyah dan Yayasan Darul Abror di Desa Sigar Penjalin, Kecamatan Tanjung, Kabupaten Lombok Utara.

Metode kegiatan yang akan dilakukan untuk tercapainya tujuan pengabdian kepada masyarakat ini adalah metode diskusi dan demonstrasi praktik langsung di lapangan yang didasari oleh hasil evaluasi awal sebagai landasan untuk menentukan posisi pengetahuan kelompok sasaran mengenai pemanfaatan lahan pekarangan melalui penerapan konsep Kawasan Rumah Pangan Lestari.

\section{Hasil dan Pembahasan}

\section{Survey Lokasi}

Survey lokasi atau survey lapangan adalah tahapan awal yang sangat penting dalam merencanakan suatu kegiatan terutama saat menentukan lokasi yang tepat yang akan dijadikan sebagai tempat menanam sayur dan membuat apotek hidup. Lokasi survey terlihat pada Gambar 1.

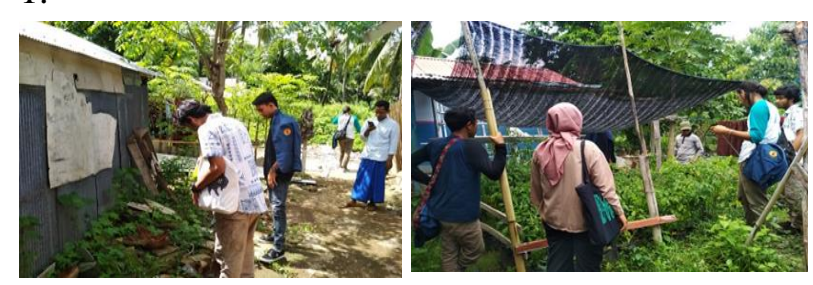

Gambar 1. Survey Lokasi Penanaman 


\section{Persiapan Media Tanam}

Media tanam merupakan faktor yang sangat menentukan sukses tidaknya penanaman berbagai jenis tanaman sayur dalam pot maupun polybag. Media tanam akan menentukan baik buruknya pertumbuhan tanaman sayur yang pada akhirnya mempengaruhi produktivitas dan kualitas dari tanaman sayur yang dihasilkan. Beberapa hal yang perlu disiapkan yaitu tanah yang kondisinya gembur dan subur, kompos atau humus, pupuk organik, pot serta polybag seperti terlihat pada Gambar 2.
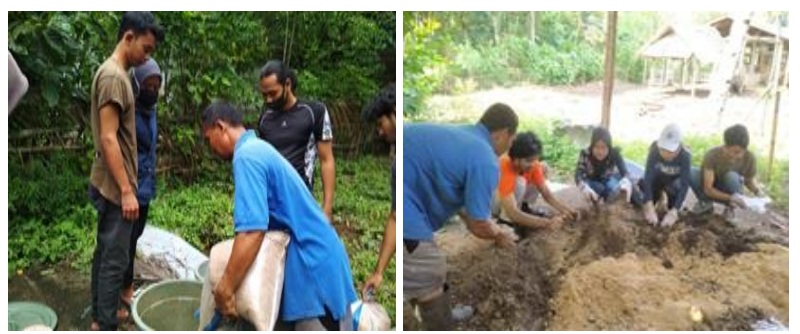

Gambar 2. Persiapan Tanah dan Pembuatan Pupuk Organik

Pupuk organik sangat bermanfaat bagi peningkatan produksi pertanian baik kualitas maupun kuantitas, mengurangi pencemaran lingkungan, dan meningkatkan kualitas lahan secara berkelanjutan. Penggunaan pupuk organik jangka panjang dapat meningkatkan produktivitas lahan dan dapat mencegah degradasi lahan. Menurut Setyaningrum (2013) bahwa manfaat dari sistem pertanian organik adalah mengurangi semua bentuk pencemaran yang dihasilkan dari berbagai kegiatan pertanian, menghasilkan bahan pangan yang cukup aman, bergizi, sehingga dapat meningkatkan kesehatan masyarakat serta meningkatkan dan menjaga produktivitas lahan pertanian dalam jangka waktu panjang.

Pembuatan Rumah Bibit

Pembuatan rumah bibit bertujuan untuk melindungi bibit sayur dari terpaan hujan dan sinar matahari berlebihan. Bahan yang digunakan adalah bambu, plastik dan paranet seperti terlihat pada Gambar 3.

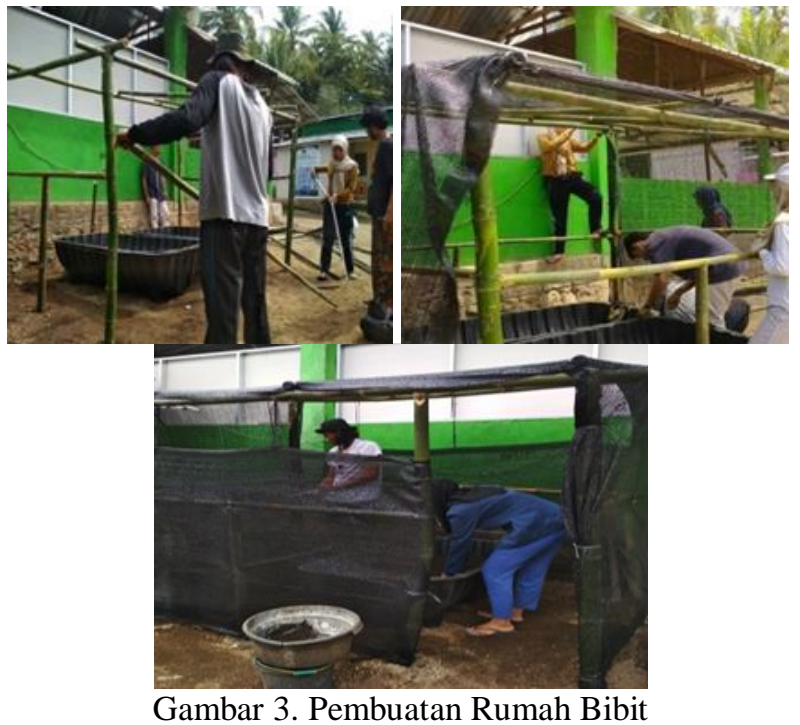

Setelah rumah bibit selesai dibangun, dilakukan pengisian pot dengan tanah dan penyemaian bibit sayur. Jenis sayur yang ditanam yaitu bibit kangkung, sawi, pakcoy, kacang panjang, cabai dan tomat. Selain berbagai jenis sayur-sayuran, ditanam berbagai jenis tanaman obat-obatan seperti kunyit, jahe dan kencur. Cara penyemaian bibit sayur adalah dengan menaburkan sedikit demi sedikit bibit di atas permukaan tanah lalu ditutup kembali dengan tanah diatasnya. Khusus untuk tanaman cabai dan tomat ditanam benih yang sudah besar ke dalam polybag, seperti terlihat pada Gambar 4.

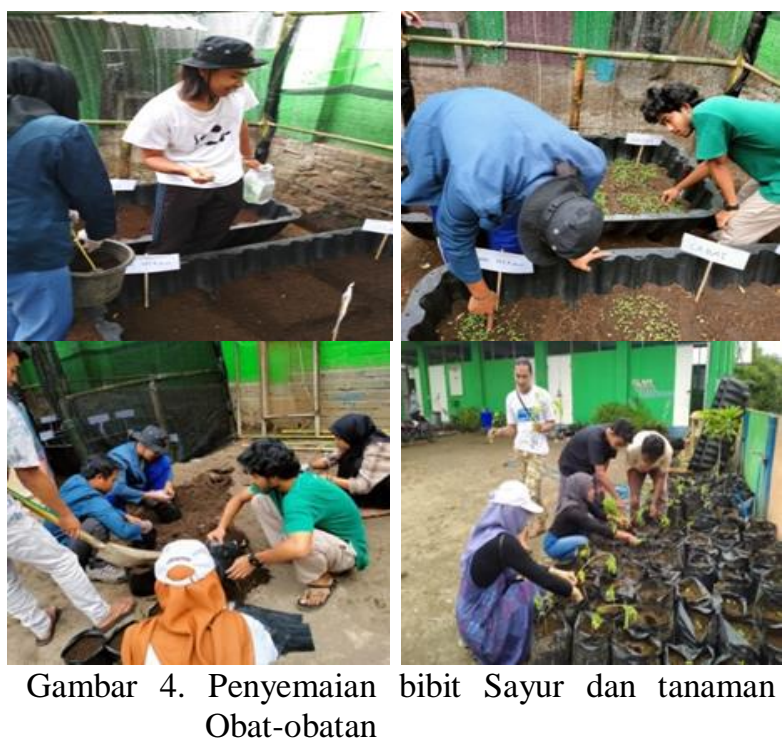


Perawatan Tanaman

Setelah bibit disemai selanjutnya dilakukan pengontrolan secara berkala untuk melihat perkembangan tanaman. Dilakukan penyiraman selama 1 kali sehari. Apabila tanaman sayur sudah terlihat tumbuh besar maka akan dipindah ke media tanam lain seperti botol aqua dan atau polybag seperti terlihat pada Gambar 5.
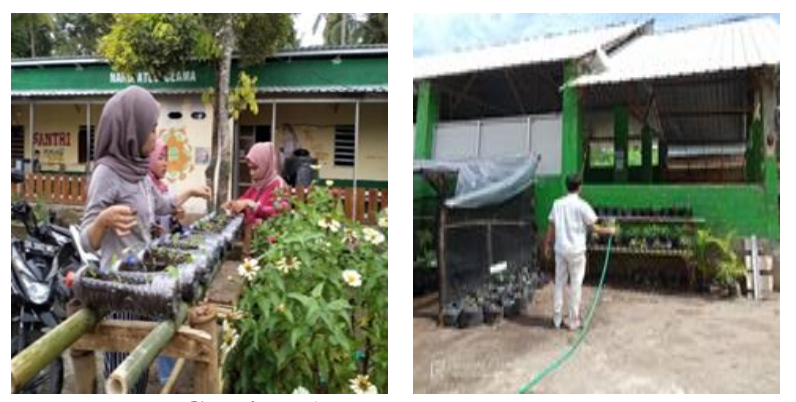

Gambar 5. Perawatan Tanaman

Kendala yang ditemukan selama proses pemeliharaan adalah tanaman layu dan ada beberapa yang mati diakibatkan oleh curah hujan yang tinggi. Menurut Servina (2019) bahwa pada saat curah hujan tinggi muncul serangan penyakit pada tanaman diantaranya penyakit layu fusarium, layu bakteri, dan antraknosa cabai. Demikian juga pada saat curah hujan rendah, terjadi serangan hama penyakit, diantaranya ulat bawang, virus kuning, dan thrips cabai. Selanjutnya dikatakan bahwa suhu udara dan curah hujan adalah faktor lingkungan yang sangat penting dalam kajian kesesuaian lahan dan tanaman. Dipertegas lagi bahwa perubahan curah hujan dan suhu udara akibat perubahan iklim akan menyebabkan kesesuaian lahan bagi tanaman sayuran.

\section{Kesimpulan}

Kegiatan pengabdian kepada masyarakat yang dimotori oleh mahasiswa KKN dapat meningkatkan pengetahuan dan keterampilan masyarakat Desa Sigar Penjalin dalam menyiapkan media tanam untuk budidaya tanaman sayur dalam pot, pemanfaatan bahan-bahan sekitar lingkungan untuk pembuatan pot/wadah tanaman dan memanfaatkan limbah biogas (bio slurry) menjadi pupuk organik cair.

\section{Ucapan Terima Kasih}

Terimakasih disampaikan kepada Rektor Universitas Mataram yang telah mendukung program KKN tematik yang dikoordinir oleh LPPM Universitas Mataram.

\section{Daftar Pustaka}

Handewi., P., S. 2011. Kawasan Rumah Pangan Lestari (KRPL): Sebagai Solusi Pemantapan Ketahanan Pangan. Lembaga Ilmu Pengetahuan Indonesia.

Kurniawan, Y., Y. Akhmad, D. Bambang, S. Yogi. 2018. Analisis Program Kawasan Rumah Pangan Lestari dan Hubungan Dengan Ketahanan Pangan Serta Kesejahteraan Rumah Tangga (Studi Kasus di Kota Surakarta). Jurnal ilmu ekonomi terapan. 3(2): 1-22.

Saliem., H., P. 2011. Kawasan Rumah Pangan Lestari (KRPL): Sebagai Solusi Pemantapan Ketahanan Pangan. Pusat Sosial Ekonomi dan Kebijakan Pertanian. Balitbangtan, Jakarta.

Servina, Y. 2019. Dampak Perubahan Iklim Dan Strategi Adaptasi Tanaman Buah Dan Sayuran Di Daerah Tropis. Jurnal Litbang Pertanian. 38(2): 65-76.

Setyaningrum. Hesti D. Saparinto. Cahyo. 2011. Panen Sayuran Secara Rutin di Lahan Sempit. Penebar Swadaya. Jakarta.

Tando, E. 2018. Optimalisasi Pemanfaatan Pekarangan Melalui Pengembangan Model Kawasan Rumah Pangan Lestari (M-KRPL) Dalam Mendukung Penerapan Teknologi Budidaya Sayuran Organic di Sulawesi Tenggara. Jurnal Agroadix. 2(1): 14-22. 